\title{
Metafora dalam Lirik Lagu "Mendarah" oleh Nadin Amizah
}

\author{
Ayudia Helmi ${ }^{1, *}$, Widya Utari ${ }^{2}$, Alya Luthifah ${ }^{3}$, Adelliya Yuwanda Putri ${ }^{4}$, Frinawaty \\ Lestarina Barus ${ }^{5}$ \\ Universitas Negeri Medan \\ *Corresponding author: email: ayudiaahelmi10@gmail.com
}

Submitted: 9 May 2021

Revised: 9 June 2021

Accepted: 8 July 2021

\begin{abstract}
The use of literary techniques such as metaphor is commonly found in imaginative writing such as song lyrics. In addition, metaphors can enrich the aesthetic and atmospheric elements in a musical work. This study aims to discuss the element of metaphor in the lyrics of the song "Mendarah" by Nadin Amizah. This research is a qualitative research with descriptive method. Data collection techniques were carried out through observation and note-taking methods. Data analysis was carried out using a direct-directed content analysis method. Analysis of the use of metaphors in the lyrics of this song can be implied in the semantic perspective. The results of this study indicate that there are 3 explicit metaphors (in praesentia) and implicit metaphors (in absentia) in the song "Mendarah". The selection of explicit metaphors (in praesentia) and implicit metaphors (in absentia) have been proportioned in such a way as to produce songs that are not only good to listen to, but also able to convey the message contained in them.
\end{abstract}

Keywords. Metaphors, song, stylistics

Abstrak. Penggunaan teknik sastra seperti metafora jamak ditemukan dalam tulisan imajinatif seperti lirik lagu. Penelitian ini bertujuan untuk mendiskusikan unsur metafora dalam lirik lagu "Mendarah" oleh Nadin Amizah. Penelitian ini berjenis penelitian kualitatif dengan metode deskriptif. Teknik pengumpulan data dilakukan melalui metode simak dan mencatat. Analisis data dilakukan dengan metode analisis isi langsung terarah. Analisis penggunaan metafora dalam lirik lagu ini dapat diiimplikasikan pada perspektif semantis. Hasil penelitian ini menunjukkan bahwa terdapat 3 metafora eksplisit (in praesentia) dan metafora implisit (in absentia) dalam lagu "Mendarah". Pemilihan metafora eksplisit (in praesentia) dan metafora implisit (in absentia) sudah diracik sedemikian rupa secara proporsional sehingga menghasilkan lagu yang tidak hanya bagus untuk didengarkan, namun juga mampu membuat pesan yang terkandung di dalamnya tersampaikan.

Keywords. metafora, lagu, stilistika.

\section{Pendahuluan}

Konsep metafora berasal dari bahasa Yunani yakni "metaphorợ". Terma ini terdiri atas dua kata yakni "meta" memiliki arti "di atas" dan "phrein" memiliki arti "membawa" (Lakoff \& Johnson, 2013). Berdasarkan gabungan dua kata tersebut, metafora dapat diartikan sebagai suatu perpindahan atau pemindahan. Menurut Tarigan (2013), metafora didefinisikan sebagai 
penggunaan kata-kata tanpa makna yang sesungguhnya, tetapi sebagai gambaran yang berlandaskan perbandingan ataupun persamaan singkat yang tersusun rapi guna menghasilkan makna lain. Lakoff dan Johnson dalam Metaphors We Live By juga mengungkapkan bahwa umumnya metafora digunakan untuk menggambarkan imajinasi puitis menggunakan aspek retorikal dan penggunaan bahasa yang luar biasa (Lakoff dan Johnson, 2013). Kemudian, Lakoff dan Johnson membagi metafora ke dalam tiga jenis yaitu metafora struktural, metafora orientasional, dan metafora ontologis. Menurut Lakoff dan Johnson, dalam melakukan analisis metafora memiliki dua komponen utama yaitu ranah sasaran dan ranah sumber. Guna dari konsep ini untuk memahami apa yang terkandung dalam metafora dengan menemukan kerakteristik antara kedua komponen utama yaitu ranah sasaran dan ranah sumber (Lakoff dan Johnson, 2013).

Nurgiyantoro (2017) menyatakan bahwa metafora merupakan perbandingan yang bersifat tidak langsung dan implisit. Struktur dasar metafora sangat sederhana. Metafora terdiri atas dua hal mengenai sesuatu yang dibandingkan dan sesuatu yang dijadikan bandingan (Nurgiyantoro, 2017). Selanjutnya, metafora diklasifikan menjadi tiga oleh Nurgiyantoro, yakni: metafora eksplisit (in praesentia), metafora implisit (in absentia), serta metafora usang. Penggunaan metafora paling lazim ditemukan dalam karya tulis imajinatif salah satunya lirik/syair lagu.

Dalam musik-selain irama, struktur kata dalam lirik juga bertindak sebagai sarana menyampaikan pesan. Wellek \& Warren menjelaskan hubungan unsur musik dan lirik lagu pada bentuk komunikasi yang dilakukan oleh komunikator kepada komunikan (Wellek dan Warren, 1989). Lirik merupakan puisi pendek yang berisikan ekspresi dari emosi. Ekspresi tersebut dimanifestasikan dalam bentuk kata dan bunyi. Lirik lagu mempunyai kaidah-kaidah yang kerap sama dengan puisi, yakni terdapatnya metafora dalam bunyi dan kata yang dipakai, baik secara eksplisit maupun implisit. Di samping itu, guna mendapat kesan tertentu seperti halnya dalam puisi, bahasa dalam lirik lagu juga bersifat ringkas dan padat (Semi, 1988)

Dalam sebuah lagu, kandungan metafora cukup memberi pengaruh pada pemaknaan maupun estetika. Hal tersebut disebabkan oleh metafora yang memperkaya makna yang terdapat dalam lagu tersebut, sehingga makna yang dimuat tidak hanya makna literal namun juga makna metaforis. Suatu lagu yang mengandung metafora membuat lagu tersebut melahirkan banyak interpretasi yang berbeda di antara para pendengarnya. Perbedaan tersebut akan menjadi nilai tambah pada lagu tersebut karena akan meraih penonton dengan rentang yang cukup luas.

Penelitian ini penting untuk dilakukan dalam upaya apresiasi dan eksplorasi kemampuan sastra yang dimiliki oleh seorang penyanyi sekaligus penulis lirik. Nadin Amizah dikenal sebagai seorang penyanyi muda yang berbakat yang selalu menyisipkan retorika indah di setiap lagunya. Album "Selamat Ulang Tahun" yang dirilis pada tahun 2020 merupakan karya tangannya sendiri, di mana salah satu di antaranya "Mendarah" menjadi salah satu judul album tersebut. Berdasarkan uraian di atas maka penelitian ini memfokuskan pada metafora lirik lagu Nadin Amizah berjudul "Mendarah", khususnya pembahasan jenis dan makna metafora dalam lirik lagu.

Lebih lanjut, penelitian terkait penggunaan aspek metafora dalam lirik lagu sudah pernah dilaksanakan sebelumnya. Terdapat penelitian perihal lagu genre pop Indonesia 80-an, 90-an, serta 2000-an, lagu pop Jepang, lagu daerah, lagu dangdut, lagu pop Barat, serta lagu pop Indonesia terbaru. Lagu bergenre pop Indonesia 80-an dan 90-an dari Ebiet G.Ade yakni "Camelia I-IV" dianalisis oleh Nitisari (2021) dan hasil penelitiannya ialah ditemukan total 44 metafora yang terdiri atas 26 metafora hidup dan 18 metafora mati. Sedangkan lagu bergenre pop Indonesia 2000-an yang dikaji ialah lagu-lagu dari lagu Agnes Mo yang diteliti oleh Dewi, 
Astuti, dan Novita (2020) yang menghasilkan bahwa dalam lagu-lagu tersebut terdapat metafora struktural, metafora orientasional, dan metafora ontologis. Lagu-lagu bergenre pop Jepang yang diteliti oleh Padmadewi, Putri, dan Darmayasa (2020) mengkaji metafora dalam lagu "First Love" dari Utada Hikaru dan menemukan bila lirik lagu tersebut mengandung metafora antropomorfik. Kemudian lagu bergenre pop Jepang lainnya yang pernah dikaji ialah "Tsugi no Ashiato" dari AKB48 yang dianalisis oleh Puspita dan Winingsih (2018), yang menemukan bila dalam lagu tersebut terdapat metafora struktural, metafora orientasional dan metafora ontologis.

Sedangkan lagu daerah yakni "Nyidam Sari" dan "Yen Ing Tawang Ono Lintang" karya Andjar Any dikaji oleh Ranabumi (Ranabumi, 2018) dan menemukan bila terdapat 13 metafora dalam kedua lagu tersebut, yakni 4 metafora nominatif, 4 metafora komplementatif, 4 metafora predikatif, dan 1 metafora kalimatif. Metafora dalam lagu-lagu yang bergenre dangdut diteliti oleh Wiradharma dan Tharik WS (2016) dan temuannya ialah terdapat metafora kreatif sebagai ungkapan yang belum terdapat dalam kamus, seperti keong racun, buaya buntung, serta 69 yang secara metaforis mengandung makna pornografi. Selanjutnya metafora dalam lagu-lagu bergenre pop Barat seperti lagu-lagu karya Taylor Swift dikaji oleh Irwansyah, Wagiati, dan Darmayanti (2019) dan menemukan bila lagu-lagu tersebut mengandung cinta yang dikonseptualisasikan dalam metafora konseptual. Metafora dalam lagu-lagu dari album "No Sound Without Silence" milik The Script dikaji oleh Garing (2016) dan menemukan bahwa lagu-lagu dalam album tersebut mengandung metafora concretive 32 baris, metafora humanizing 6 baris, metafora animistics 1 baris dan metafora synaesthetic 3 baris.

Selanjutnya, lagu pop Indonesia yang tergolong baru seperti lagu "Sepatu" karya Tulus dikaji oleh Astuti (2019) dan kajian tersebut menghasilkan bahwa metafora yang terkandung dalam metafora tersebut merupakan metafora orientasional. Lebih lanjut, lagu lain dari Nadin Amizah yang berjudul "Seperti Tulang" diteliti oleh Fitri, Sobari, dan Kamaluddin (2020) dan menemukan bahwa terkandung majas personifikasi, majas retorika, dan majas paradoks.

Secara fundamental perbedaan penelitian terdahulu dengan penelitian ini terletak pada objek yang dikaji serta metafora yang hendak diteliti. Lagu "Mendarah" karya Nadin Amizah dipilih guna dikaji karena lagu tersebut belum pernah diteliti sebelumnya. Sehingga hasil penelitian ini nantinya mampu memperkaya literatur perihal pengkajian metafora dalam lagu serta dapat pula menjadi referensi guna penelitian sejenis di masa mendatang.

\section{Metode}

Penelitian ini berjenis penelitian kualitatif. Seperti yang dipaparkan Sugiyono (2015) bahwa penelitian kualitatif berusaha menjelaskan makna dibalik data kualitatif yakni data nonangka yang tidak dapat dihitung. Penelitian ini menggunakan metode deskriptif analitik dengan ancangan strukturalisme dan proposisi. Penelitian ini menggunakan metode kualitatif karena data yang diperoleh adalah berupa data deskriptif dan memberikan gambaran atau lukisan secara sistematis, faktual, dan akurat mengenai metafora dalam semantik kognitif pada lirik lagu "Mendarah". Penulis juga menggunakan metode kepustakaan dalam mencari sumber data yang mendukung penelitian dengan cara mempelajari permasalahan penelitian menggunakan sumber literatur yang dijadikan sebagai rujukan.

Data dalam penelitian ini berupa kalimat-kalimat yang mengandung metafora dalam lirik lagu "Mendarah". Sumber data penelitian ini berupa lagu yang berjudul "Mendarah". "Mendarah" merupakan salah satu lagu yang ada di dalam album Selamat Ulang Tahun yang dirilis pada tahun 2020 silam. Lagu tersebut terdiri atas satu stanza yang berisikan 26 larik. 
Pengumpulan data penelitian ini dilakukan dengan teknik pencatatan (Sugiyono 2015). Teknik pencatatan digunakan dalam penelitian untuk mencatat hal-hal penting dan yang diperlukan penelitian yang dilakukan sebelum dan sesudah dari penelitian. Beberapa tahapan langkah-langkah pengumpulan data:

Langkah pertama yang dilaksanakan ialah mempersiapkan segala sesuatu terkait teori yang mendukung dan berkorelasi dengan topik penelitian melalui pemanfaatan sejumlah literatur. Selanjutnya lirik lagu "Mendarah" dalam album Selamat Ulang Tahun diamati guna mendapat temuan metafora. Lalu kata-kata dalam lagu yang diklasifikasikan mengandung metafora dikorelasikan dengan pemaknaan lagu.

Sedangkan analisis data metafora dalam lirik lagu "Mendarah" menggunakan teknik analisis isi langsung terarah. Teknik ini digunakan untuk menggambarkan isi pesan pada makna kata yang mengalami perubahan makna dalam kalimat tulis bahasa kias. Maka disimpulkan bahwa teknik analisis isi merupakan teknik mengamati serta menganalisis isi pesan guna untuk melihat perubahan makna pada kalimat yang menggunakan bahasa kias.

Tahapan analisis data yang dilakukan oleh penulis yaitu dengan membaca dan mencatat ujaran-ujaran dalam lirik lagu yang mengandung metafora, kemudian mengkodifikasikan data, selanjutnya mengelompokkan jenis metafora berdasarkan pendapat Nurgiyantoro (2017). Untuk pemaknaan dari metaofra, dilakukan interpretasi dengan menguraikan data satu per satu kemudian menuliskan hasil tafsiran tersebut dan menyimpulkan hasil analisis yang telah dilakukan terhadap ujaran-ujaran lagu yang memiliki metafora dalam lirik lagu "Mendarah" karya Nadin Amizah.

\section{Hasil dan Pembahasan}

Hasil analisis dari penelitian ini adalah kata-kata yang mengandung metafora seperti berikut ini.

\section{Lirik Lagu "Mendarah"}

Bagaikan jiwa yang terpisah

Mati enggan, hidup pun susah

Jiwanya tlah lama direnggut waktu

Katanya hatiku tlah lama terbelah

Bagai cangkang kosong terpisah

Ragaku ada disini tapi hatiku bersamamu

Bukan maaf yang kuminta

Tapi peluk yang kulupa

Ini cerita tentang rumah yang berbeda

Dan berjarak jauh

Hanya tersentuh dalam jarak doa

Ada hati yang kujaga

Namamu jadi rahasia

Dalam diam kan kubawa

Mendarah 
Setidaknya ada cerita

Dimana ada kamu dalamnya

Ini cerita tentang rumah yang berbeda

Dan berjarak jauh

Hanya tersentuh dalam jarak doa

Ada hati yang kujaga

Namamu jadi rahasia

Dalam diam kan kubawa

Dalam diam kan kubawa

Dalam diam kan kubawa

Mendarah

Lagu tersebut mempunyai makna umum perbedaan tempat, atau lebih spesifiknya adalah dua rumah yang berbeda antara satu yang ditempati penulis lagu dengan rumah lain yang ia maksudkan dalam lagu tersebut. Interpretasi tersebut dapat dipahami melalui lirik yang tertulis secara eksplisit "Ini cerita tentang rumah yang berbeda", "Dan berjarak jauh", "Hanya tersentuh dalam jarak doa" yang disebutkan setidaknya dua kali . Sedangkan menurut peneliti makna lain yang terkandung ialah meskipun terpisahkan jarak, terdapat perasaan penulis lagu terhadap seseorang yang mendiami tempat ataupun rumah lain. Perasaan tersebut tidak diungkapkan secara langsung sebab penulis lagu merasa perlu menjaga hati seseorang yang mendiami tempat ataupun rumah yang sama dengan dirinya. Hal tersebut ditunjukkan melalui frasa "dalam diam kan kubawa" yang disebutkan berulang-ulang.

Tabel 1. Pengklasifikasian Temuan Metafora dalam Lirik Lagu

\begin{tabular}{|c|l|l|}
\hline No & \multicolumn{1}{|c|}{ Data } & \multicolumn{1}{c|}{ Tipe Metafora } \\
\hline 1 & Mati enggan, hidup pun susah & Metafora Eksplisit (In Praesentia). \\
\hline 2 & Jiwanya tlah lama direnggut waktu & Metafora Eksplisit (In Praesentia). \\
\hline 3 & Katanya hatiku tlah lama terbelah & Metafora Implisit (In Absentia) \\
\hline 4 & Ragaku ada disini tapi hatiku bersamamu & Metafora Eksplisit (In Praesentia) \\
\hline 5 & $\begin{array}{l}\text { Dalam diam kan kubawa, } \\
\text { mendarah }\end{array}$ & Metafora Implisit (In Absentia). \\
\hline
\end{tabular}

Tarigan berpendapat bila semantik merupakan telaah lambang atau tanda yang menyatakan korelasi antarmakna dan pengaruhnya terhadap manusia dan masyarakat (Tarigan 2015). Berlandaskan pendapat tersebut, maka data nomor 1,2, dan 4 pada kolom 1 dikategorikan dalam metafora eksplisit sebab lirik-lirik tersebut dapat dipahami secara literal. Sementara data nomor 3 dan 5 pada kolom 1 dikategorikan dalam metafora implisit sebab diperlukan penelaahan lebih lanjut terhadap lirik-lirik tersebut dan makna yang dikandungnya. 
Tabel 2. Hasil Analisis Kata-kata yang Mengandung Metafora

\begin{tabular}{|c|c|c|}
\hline No & Sumber & Sasaran \\
\hline 1 & Mati enggan, hidup pun susah & $\begin{array}{l}\text { Baris kedua dari lirik lagu ini bermakna keputus asaan } \\
\text { akan hidupnya, kata mati mengibaratkan keinginan } \\
\text { penulis untuk tetap bertahan atas semua yang ia alami } \\
\text { sedangkan kata hidup mengibaratkan kesusahan hati } \\
\text { yang dihadapi penulis. Pada baris ini, terlihat penulis } \\
\text { seperti serba salah akan hidupnya antara harus mati } \\
\text { atau hidup. Penulis tidak ingin mati, ingin tetap hidup, } \\
\text { namun kehidupannya terasa berat. }\end{array}$ \\
\hline 2 & Jiwanya tlah lama direnggut waktu & $\begin{array}{l}\text { Baris ketiga dari lirik lagu ini bermakna jiwa penulis } \\
\text { yang telah mati bersama dengan perpisahan yang } \\
\text { dihadapinya }\end{array}$ \\
\hline 3 & Katanya hatiku tlah lama terbelah & $\begin{array}{l}\text { Baris keempat pada lirik lagu ini bermakna sulitnya } \\
\text { menerima perpisahan yang tlah terjadi walau sudah } \\
\text { lama }\end{array}$ \\
\hline 4 & $\begin{array}{l}\text { Ragaku ada disini tapi hatiku } \\
\text { bersamamu }\end{array}$ & $\begin{array}{l}\text { Baris kelima pada lirik lagu ini berisikan pernyataan } \\
\text { dari penulis bila raganya berada di tempat yang } \\
\text { terpisah dengan tempat di mana hatinya (perasaannya } \\
\text { berada). }\end{array}$ \\
\hline 5 & $\begin{array}{l}\text { Dalam diam kan kubawa, } \\
\text { mendarah }\end{array}$ & $\begin{array}{l}\text { Baris keempat belas - lima belas saling berkaitan, } \\
\text { perpisahan fisik tak dapat memisahkan ikatan darah }\end{array}$ \\
\hline
\end{tabular}

Data pada kolom 1 dikategorikan sebagai "sumber" sebab data tersebut merupakan lirik-lirik dari lagu "Mendarah" karya Nadin Amizah. Sementara data pada kolom 2 dikategorikan sebagai "sasaran" sebab data tersebut berisikan interpretasi dan hasil penelaahan dari peneliti terhadap lirik-lirik dalam lagu "Mendarah".

\section{Pembahasan}

Melalui lirik lagu yang ditulisnya, Nadin Amizah menerangkan bahwa perpisahan fisik tak bisa memisahkan darah yang mengalir. Terdapat 3 metafora eksplisit (in praesentia) dan 2 metafora implisit (in absentia). Berikut lirik-lirik yang diklasifikasikan sebagai metafora eksplisit (in praesentia) beserta penjelasannya. Lirik "Mati enggan, hidup pun susah" dikarenakan keadaan yang membuat hidup yang dijalani terasa susah dan berat, namun masih enggan untuk mati. Kemudian lirik "Jiwanya tlah lama direnggut waktu" karena sudah jelas bila jiwa dalam larik tersebut sudah direnggut, dikikis sedikit demi sedikit oleh waktu yang terus berlalu. Selanjutnya lirik "Ragaku ada disini tapi hatiku bersamamu" karena memuat pernyataan dari penulis bila raga dan hatinya tidak berada di satu tempat yang sama. Raga penulis berada di sini (suatu tempat tertentu) sementara hatinya bersama orang yang berada di tempat berbeda.

Sedangkan lirik-lirik yang dilkasifikasikan sebagai metafora implisit (in absentia) ialah lirik "Katanya hatiku tlah lama terbelah" sebab terdapat kata "katanya" yang berarti asumsi dari orang lain, namun tidak juga ada sanggahan dari penulis yang menyatakan sebaliknya sehingga dapat diasumsikan bila penulis membenarkan asumsi tersebut. Selanjutnya lirik "Dalam diam 
kan kubawa, mendarah" lantaran terdapat maksud tidak langsung yang disampaikan melalui kata "dalam diam" yang berarti penulis tidak melakukannya secara terang-terangan.

Temuan-temuan tersebut berkorelasi dengan genre pop yang ia usung dikarenakan jika terlalu banyak metafora implisit yang terdapat dalam lagu, akan membuat pendengar perlu benar-benar memahami maksudnya. Sedangkan metafora eksplisit yang lebih banyak memudahkan para pendengar guna memahaminya dikarenakan metafora eksplisit lebih mudah dicerna.

\section{Simpulan}

Hasil penelitian ini menunjukkan terdapat penggunaan 3 metafora eksplisit (in praesentia) dan 2 metafora implisit (in absentia) pada lirik lagu Mendarah yang bertujuan untuk mengibaratkan makna sebenarnya yang dimaksud dalam bentuk konkrit dari lagu tersebut adalah rasa sakit seorang anak atas perpisahan Ayah dan Ibundanya. Pesan yang disampaikan dalam lagu tersebut disajikan dalam bahasa yang mengandung metafora agar terdengar indah namun terkesan mendalam jika diketahui maknanya.

Pemilihan metafora eksplisit (in praesentia) dan metafora implisit (in absentia) sudah diracik sedemikian rupa secara proporsional sehingga menghasilkan lagu yang tidak hanya bagus untuk didengarkan, namun juga mampu membuat pesan yang terkandung di dalamnya tersampaikan. Lebih lanjut, sebuah lagu bakal terus selalu diingat ketika banyak orang yang merasa mempunyai "ikatan" dengan lagu tersebut dan merasa terwakili lantaran kisah hidup yang tidak jauh berbeda. Kata Mendarah dari judul lagu ini diambil Nadin dari frasa mendarah daging, yang memiliki makna sangat meresap ke dalam hati sanubari, atau bisa disebut dengan sudah menjadi kebiasaan. Lirik lagu "Mendarah" ini Nadin tulis untuk seseorang yang jauh dari raihannya, namun selalu disertakan dalam doa

Penggunaan metafora dalam lagu "Mendarah" karya Nadin Amizah membawanya menjadi penyanyi muda yang mempunyai kekhasan tersendiri. Hal tersebut dapat diamati melalui komentar-komentar pada kanal YouTube miliknya ataupun mealui akun-akun media sosial yang ia miliki. Tentu saja Nadin bukanlah satu-satunya penyanyi yang menggunakan metafora dalam lagu-lagu yang dinyanyikannya, namun pemilihan kata yang dibalut metafora miliknya mampu membuat namanya diingat banyak orang, lagu-lagunya didengarkan, serta membuat dirinya memikat banyak penggemar.

\section{Referensi}

Astuti, W. Y. (2019). “Metafora Bentuk Bahasa 'Sepatu' dalam Lirik Lagu 'Sepatu' Karya Tulus." SEMITRA IV: Seminar Nasional Literasi IV 4 (1): 401-8. http://conference.upgris.ac.id/index.php/snl/article/view/817.

Dewi, FPK, P. P. Astuti, dan S. Novita. (2020). 'Metafora Dalam Lirik Lagu Agnez Mo' Asas: Jurnal Sastra 9 (2): 72-80.

Fitri, N., T. Sobari, dan T. Kamaluddin. (2020). 'Majas Dan Makna Pada Lirik Lagu Nadin Amizah Yang Berjudul Seperti Tulang'. Parole (Jurnal Pendidikan Bahasa dan Sastra Indonesia) 3 (5): 785-96.

Garing, D. (2016). 'Metafora pada Lirik-Lirik Lagu dalam Album No Sound Without Silence Karya The Script'. Jurnal Elektronik Fakultas Sastra Universitas Sam Ratulangi 2 (1): $1-14$. 
Irwansyah, Wagiati, dan N. Darmayanti. (2019). "Metafora Konseptual Cinta Dalam Lirik Lagu Taylor Swift : Kajian Semantik Kognitif." Metahumaniora 9 (2): 224-31.

Lakoff, G., \& M Johnson. (2013). Metaphors We Live By. Metaphors We Live By. Chicago: University of Chicago Press. https://doi.org/10.7208/chicago/9780226470993.001.0001.

Nitisari, Dwi. (2021). "Metafora dalam Lagu Ebiet G. Ade 'Camelia I-IV." UG JURNAL 15 (1): $30-40$.

Nurgiyantoro, B. (2017). Stilistika. Yogyakarta: Gadjah Mada University Press.

Padmadewi, AAAD, ME Putri, dan GO Darmayasa. (2020). "Analisis Metafora Dalam Lirik Lagu “ First Love Utada Hikaru ."” JPBJ 6 (2): 283-86.

Puspita, D., dan I. Winingsih. (2018). "Metafora pada Lirik Lagu AKB48." Journal of Chemical Information and Modeling 14 (1): 55-68.

Ranabumi, R. (2018). "Metafora Pada Lagu Nyidham Sari dan Yen Ing Tawang ono Lintang." Ranah: Jurnal Kajian Bahasa 7 (2): 247-62. https://doi.org/10.26499/rnh.v7i2.659.

Semi, M. A. (1988). Anatomi Sastra. Padang: Angkasa Raya.

Sugiyono. (2015). Metode Penelitian dan Pengembangan Pendekatan Kualitatif, Kuantitatif, dan $R \& D$. Bandung: Alfabeta.

Tarigan, H. G. (2013). Pengajaran Gaya Bahasa. Bandung: Angkasa. (2015). Pengajaran Semantik. Bandung: Angkasa.

Wellek, R., \& A. Warren. (1989). Theory of Literature. Harcourt: Brace\&Company.

Wiradharma, G., dan Afdol Tharik WS. (2016). "Metafora Dalam Lirik Lagu Dangdut: Kajian Semantik Kognitif." Arkhais - Jurnal Ilmu Bahasa dan Sastra Indonesia 7(1): 5-14. https://doi.org/10.21009/arkhais.071.02. 